\title{
Urban Development in the Cities of the Tell Atlas Mountains Region of Northern Algeria: Médéa as a Model
}

\author{
Azzeddine BELLOUT ${ }^{*}{ }^{*}, 2$, Mohamed Abdessamad REZZAZ3, Christopher BRYANT4, 5 \\ * Corresponding author \\ ${ }^{1}$ Teacher Training School of Bouzareah (ENS), Algiers, ALGERIA \\ ${ }^{2}$ University Akli Mohand Oulhadj of Bouira, Bouira, ALGERIA \\ 3 University of Sciences and Technology Houari Boumediene (USTHBO), Algiers, ALGERIA \\ 4 University of Montreal, Faculty of Arts and Sciences, Department of Geography, Montreal, CANADA \\ 5 University of Guelph, School of Environmental Design and Rural Development, Guelph, CANADA \\ E-mail: a.bellout@univ-bouira.dz,drezmas@yahoo.fr, christopher.robin.bryant@gmail.com \\ DOI: 10.24193/JSSP.2020.1.05 \\ https://doi.org/10.24193/JSSP.2020.1.05
}

K e y w o r d s: urban growth, development planning, Tell Atlas Mountains, rurality, agriculture

\begin{abstract}
A B S T RA C T
Most of the mountain population in the developing world lives in urban areas and cities, mainly driven by three factors: increased population, higher incomes and lower transport costs. An urban policy for mountainous areas in Algeria is necessary to achieve sustainable development to reduce spatial disparities at the local, regional and national levels. This paper presents the results of a study of the urban development of the city of Médéa and its implications for the planning policy of mountain areas in Algeria using an analysis of data on socio-economic and environmental indicators and of the maps illustrating the city's urban expansion. The results indicate the limited design of current urban policy, which is inconsistent with the development goals of mountain cities, the failure to reform land market, continued indiscriminate growth, and the multifaceted effects on rural areas in terms of their population and agricultural functions.
\end{abstract}

\section{INTRODUCTION}

Our planet has become a planet of cities. More than half of the world's population lives in cities, and this proportion is expected to rise to $70 \%$ or more by 2050. The global urban population is expected to rise from 3.5 billion in 2010 to 6.2 billion in 2050, and most likely all this growth will occur in the least developed countries (Angel et al., 2012). The growth rate of urban dwellers in developing countries is roughly the same as that experienced by the European countries in the period 1890-1900, so it can be concluded that developing countries have been on the same path as
Europe for more than a century, having a similar experience in rushing to cities proved by the same speed and the same means.

The enormous economic growth and the dynamic development of communications and transport along with globalization of international relations have influenced mountainous areas. Mountain regions development has been a significant issue debated world-wide, with particular concerns for mountainous countries (Kreutzmann, 2001; Jansky et al., 2002; Gurung et al., 2012; Maselli, 2012). The emergence and development of cities also represent a long-term endeavour and an inevitable result of our 
continuous deepening development of natural resources and environment. Therefore, a modern city does not only serve as a place for gathering elements of population and consumption, but also plays a leading role in social production and environmental pollution through agglomerations (Stren et al., 1992; Riffat et al., 2016; Ding and Peng, 2018). It is important to coordinate the relationship between urban development and environment exploitation.

\subsection{Urban development in mountainous cities}

Mountains extend over approximately 24\% of the land surface of the earth (Löffler et al., 2011; Tiwari et al., 2018) and constitute home for nearly $12 \%$ of the world's population (Beniston, 2003). About 10\% of the world's population depends directly on the use of mountain resources for their livelihoods and well-being, and an estimated $40 \%$ depends indirectly on them for water, hydroelectricity, timber, biodiversity and niche products, mineral resources, recreation, and flood control (The Panos Institute, 2002). Despite their important contribution, mountainous regions are still marginalized in the development agenda (ICIMOD, 2012a). In response to the challenge of urbanization, studying, protecting, and developing mountainous areas have become major issues for the sustainable development in most countries (Blyth et al.,2002). Recently, awareness has been growing that a stronger differentiation is required for mountain areas. Whereas changes in mountain systems in developing countries have a direct influence on the livelihoods and food security of millions of people, changes in the mountains of industrialized countries are perceived more in the categories such as tourism and recreation (Schild and Sharma, 2011).

High economic growth and the dynamic development of communications and transport with globalization of international relations have affected urban growth in the mountains of Asia, Latin America and Africa. Urban growth is a quantitative and demographic process and, to some extent, a spatial process, involving an increased population concentration with implications for the physical growth of the city. The consequences of these effects are translated into horizontal and vertical growth, depending on the situation (Medina do Nascimento, 2009). Researchers have various opinions, to some extent, in determining the causes of urban growth, but most of them agree on three main reasons, namely (Liu et al., 2019):

- demographic increase (birth rate being greater relative to mortality rate);

(migration);

- rural populations moving to cities

- small cities transforming into important locations for the concentration of various activities.
At a first glance, it is often believed that urban growth is proportional to demographic growth, but the issue goes beyond a simple mathematical relationship since there are other factors that affect and control urbanization, in general. Geophysical components affect the development of built-up areas. The terrain and the existence of areas that cannot be reclaimed, which are unsuitable for construction (e.g. glaciers, lakes, steep slopes, amongst other conditions), limit space availability, thereby reducing the possibility of urbanization. However, some studies shown that the spread of residential and industrial areas is less feasible in mountain environments than on land in the plain areas (Verburg et al., 2004).

However, mountain regions have long been marginalized from the viewpoint of sustainable development (ICIMOD, 2012b). Thus, urbanization processes have been mostly unplanned and unregulated. As a result, urbanization has emerged as one of the important drivers of environmental change, transforming the Atlas Mountains, as well.

More recently, comparatively less accessible areas have also experienced a process of rapid urbanization mainly owing to: improved road connectivity, publicity and marketing of new tourist sites and the resultant growth of domestic and international tourism; development of horticulture; economic globalization and gradual transformation from primary resource development practices to secondary and tertiary sectors; and of course, the absence of urban land use policy (Ghosh, 2007; Tiwari et al., 2018).

\subsection{Mountainous regions in Algeria and their characteristics}

Algeria is known to be one of the mountainous countries in the world, located in the northern part of the Tell Atlas Mountains, stretching along the northern part of the country and bordering the high steppe plains (Fig. 1), which are of paramount importance in socioeconomic development. They represent a potential space for the redeployment of certain activities and the establishment of basic infrastructure necessary for the maintenance of population and territorial attractiveness. These zones cover all or part of the 28 provinces (wilayas) in the North and 453 municipalities, or $29 \%$ of the national total area. They occupy a total agricultural area of 2.53 million hectares (61\% of the total area of the mountainous areas) including a useful agricultural area of about 1.7 million hectares (i.e. $20 \%$ of the national used agricultural area). Forests cover an area of more than 1.6 million hectares and the roads cover nearly 519988 hectares (MEAT, 2003).

Mountain population represents $46 \%$ of the total population (ONS, 2008). Because of the complex 
terrain, limited land resources and fragile ecosystems, it is clear that in relation to a spatial development strategy, the manner and approach present in mountainous regions should be different from those of lowland areas because of the general structure of many mountains, consisting of ridges and valleys.

This features comparatively great absolute height and relative height, and large cutting depth. It is usually located in regions with active tectonic movement and external erosion effects, and with a complex geological structure (Du Chunlan, 2009; Wei,
2001; Huang, 2006; Wang and Lu, 2018). Increasingly, mountainous areas face ecological degradation and environmental deterioration (Beniston, 2003), with their specific regional characteristics gradually disappearing.

The human-land relationship has become increasingly intensified. It has therefore become necessary to develop an urban policy for the mountainous regions of Algeria to achieve sustainable development in order to reduce spatial disparities at the local, regional and national levels.

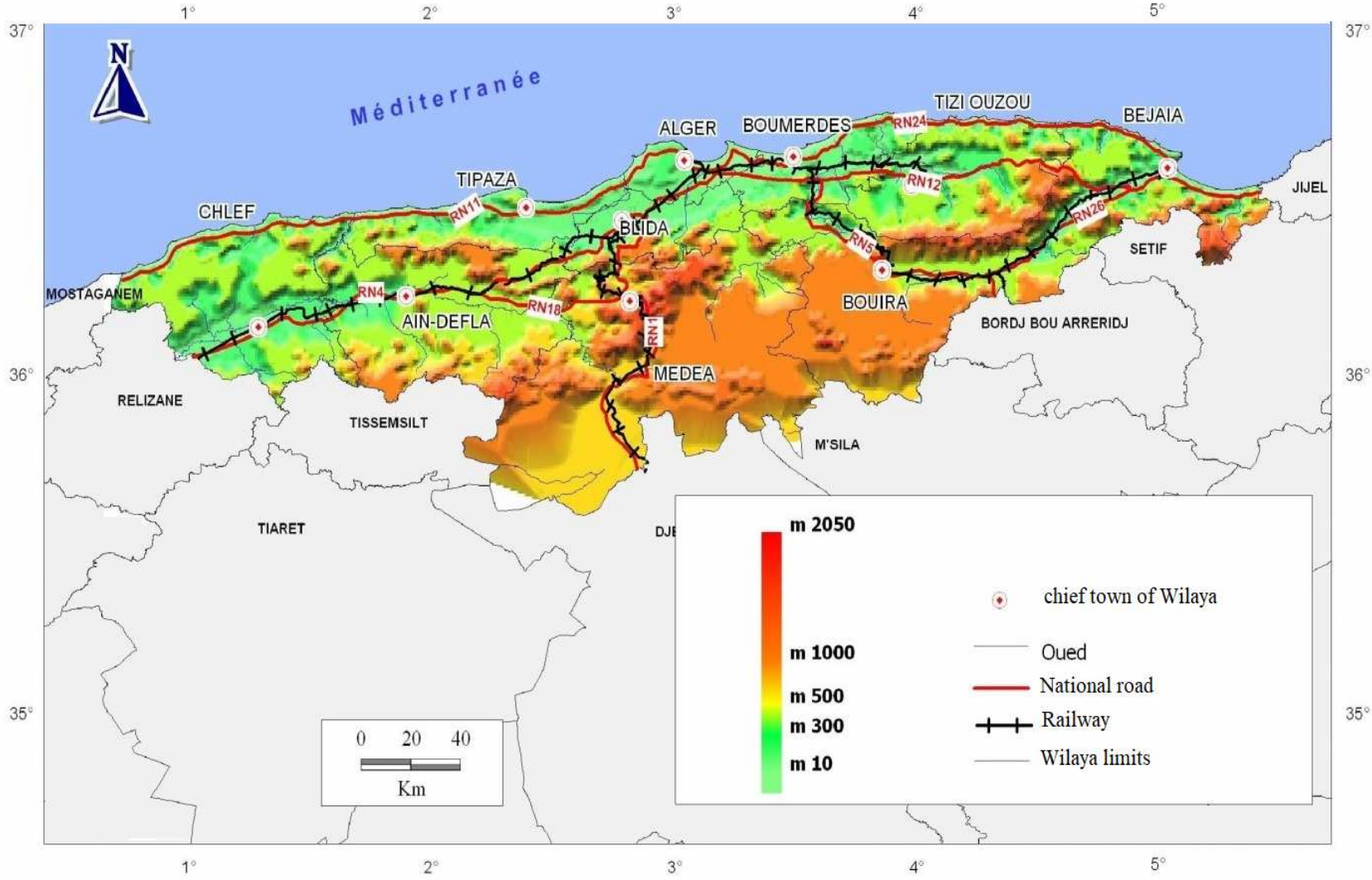

Fig. 1. Physical environment of the north-central region in Algeria. Source: (ONS) Office National des Statistiques, 2008.

A city located in a mountainous area is simply defined as a mountainous city. The built-up areas of a mountainous city are generally distributed in valleys, around ponds or lakes or on gently sloping lands, surrounded by rugged terrain. The urban area includes all the built-up land within the city's neighbourhoods. We also aim to illustrate the effects of terrain on the urban landscape and changes in urban design, and on the structure and ecological environment. However, biased guiding principles and philosophy of development have led to many problems, such as cramming improper development activities and blindly copying theories and practices from the plain areas (Zhang et al., 2015).

In order to reach the objectives of the study related to urban development in the mountainous cities in Algeria, the city of Médéa was chosen as a model for this study as one of the most important mountainous cities centred in the Atlas Mountains, which had a role like the other Algerian cities throughout Algerian history.

\section{DATA AND METHODS}

\subsection{Data}

This study aims at presenting an overview of the process of urbanization and its environmental and socio-economic impacts across the Tell Atlas Mountains region in the north of Algeria by focusing on studying the city of Médéa as a model for the rapidly growing cities of the Tell Atlas Mountains in order to assess the impacts of urbanization on the natural ecosystem.

The relevant data and information of these parameters were collected through comprehensive socio-economic surveys. With respect to this, we chose the descriptive approach through which interpretative views were taken about the area studied - a virtual view 
contributes to understanding the complex meaning of the constituent elements of our research subject.

\subsection{Methods}

The research strategy is based on the socioeconomic and environmental indicators collected from the official bodies and their published annual reports for 2008, as the latest statistics published by the official bodies of the Algerian government, because the statistical recordings in Algeria take place every ten years, and due to the lack of the final report of the last census, which was completed in 2019, and was based on the 2008 publications' reports. We also carried out an
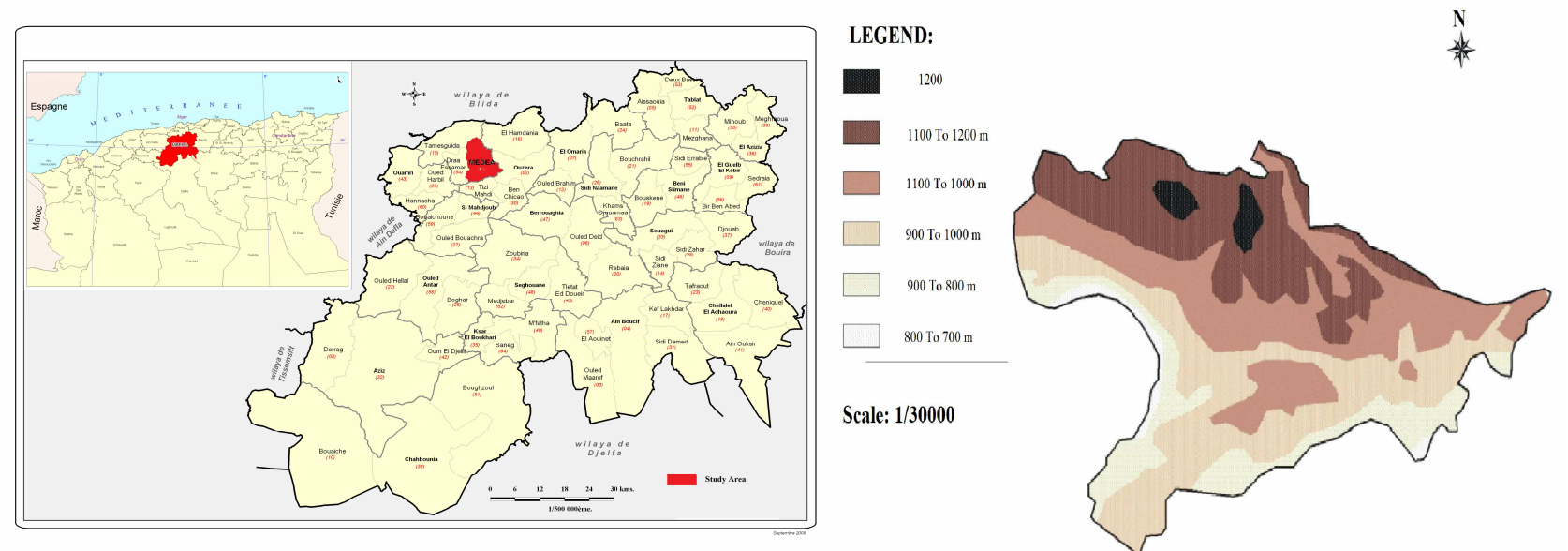

analysis of these data to identify the factors that control and influence urban development in mountain cities and their effects on the living and environmental environment. In addition, much reliance was placed on the urban expansion maps of Médéa.

\subsection{Study area}

The city of Médéa is the capital of Médéa Province, located in the Atlas Mountains, in the northern part of Algeria. Its height ranges between 800-1000 meters above the sea level with an area of 64 $\mathrm{km}^{2}$ (Fig. 2).

Fig. 2. Location and altitude classes. Source: Plan directeur d'aménagement et d'urbanisme de la commune de Médéa (PDAU, 2011).

This location near the capital and the coast has contributed to the economic importance of the city. It is the south gate towards the north. Geographically, it is located between the latitudes of $36^{\circ} 14^{\prime} \mathrm{N}$ and $36^{\circ} 20^{\prime} \mathrm{N}$, and longitudes of $2^{\circ} 43^{\prime} \mathrm{E}$ and $2^{\circ} 48^{\prime} \mathrm{E}$.

The city is characterized by a high altitude and large terrains with some quite fertile plains, but its small stretch fades at the edge of the High Plains:

a). This coastal city is positioned on a wavy plateau between $800 \mathrm{~m}$ and $1000 \mathrm{~m}$ above sea level, which represents a meeting point between the southern foothills of Blida Atlas with the extension of the southern plateau (Fig. 3).

b). The slopes above $20 \%$ are the most prevalent in the north of the city, as well as on the southern and eastern sides.

c). About $95 \%$ of the city's urban development is between an elevation of $900 \mathrm{~m}$ and $950 \mathrm{~m}$.

Many cities in Algeria have experienced accelerated reconstruction and there was no successful way to control them; this increased the need for cities to continuously expand and get rid of the suffocation resulting from the process of accelerated and often chaotic urbanization along with large rural to urban migration.
The city of Médéa has experienced the same situation, having to deal with all the difficulties and problems faced by large cities: overcrowding of their urban fabric; extremely heavy traffic; and increasing congestion day by day, which negatively affects the lives of citizens.

With the problems posed by this urban growth so far, the demand for housing and infrastructure has become more acute, and urban policies for management and planning are based on urban planning tools aimed at controlling urban growth. However, this administrative process has become extremely complex, due to the amplification of urbanization problems, particularly in recent years, characterized by economic and political changes that have emerged through the liberalization of market economy and urban land issues.

Based on the map of the urbanization of the city of Médéa (Fig. 4) we can note how the urban fabric of the old city has evolved in all directions to reach the current urban form of the city, and also that the period of the late 1970s was the period of the greatest urban expansion of the city resulting mainly from the great demographic growth estimated at $3.9 \%$, which exceeds the national average of $3.5 \%$ (ONS, 2008); this is the result of political stability after Algeria's independence. 
This situation requires that urbanization should meet the needs of population in relation to the necessary housing and appropriate structures.

As we mentioned above, the city witnessed a process of random urban expansion in which constructions extended chaotically without submitting to the plans of construction and reconstruction in the

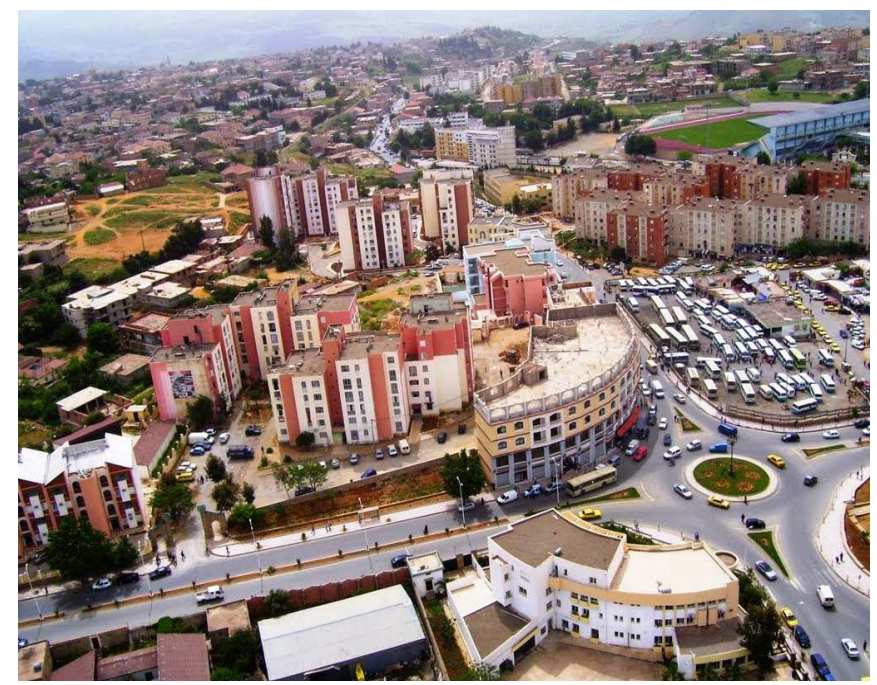

Fig. 3. City of Médéa (2018).
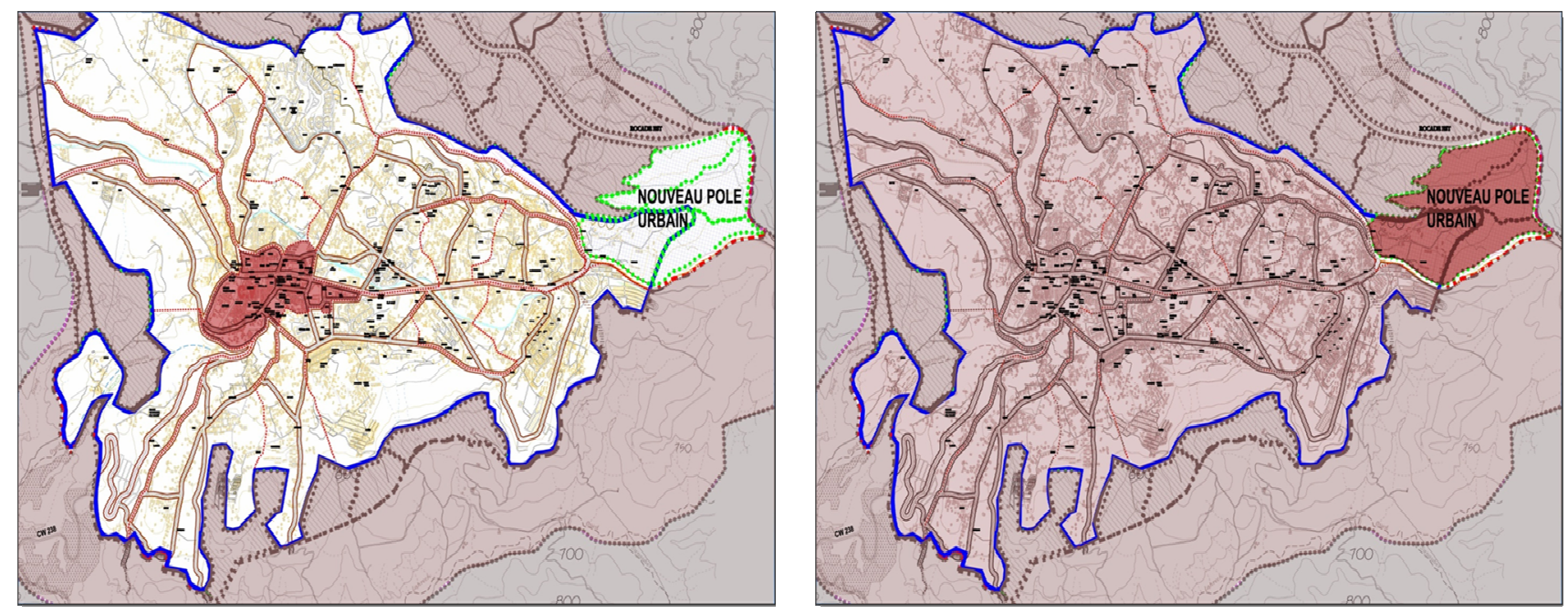

absence of strict control of the State. Residential neighbourhoods consisting of this type of construction lack public facilities and the main facilities that ensure the decent living of citizens (Fig. 4). The arbitrary growth of cities is very common in developing countries that lack the means to control reconstruction.

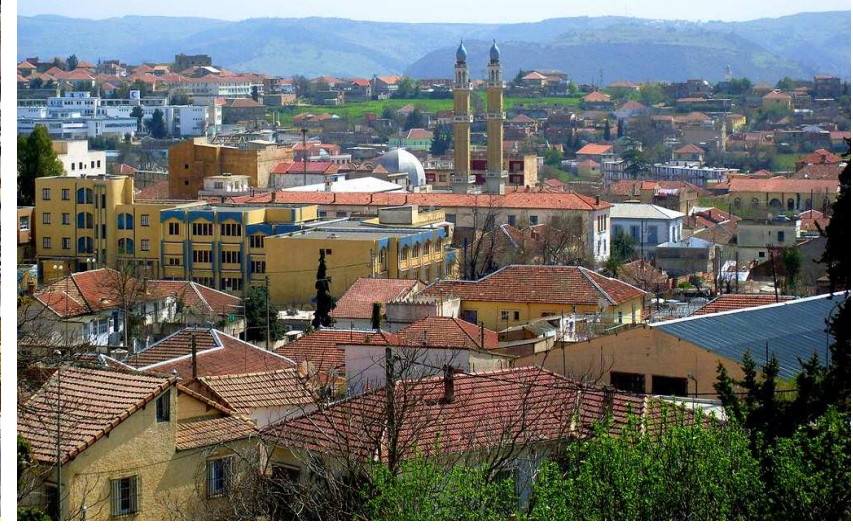

Fig. 4. Urban sprawl of Médéa. Source: Plan directeur d'aménagement et d'urbanisme de la commune de Médéa (PDAU,

2011).

\section{RESULTS AND DISCUSSION}

\subsection{Socio-economic indicators}

Social and economic indicators are the basic foundation in the identification of urban development (Carrier and Laurent, 1966; Obudho, 1976). Table 1 shows the evolution of population in the city of Médéa and the percentage of population involved in three broad economic sectors.

Referring to Table 1 and Figure 4 and 5, we note that: a). The majority of the city's population is employed in the services sector, which is linked to the fact that Médéa is the capital city of the state and has the major regional and administrative influence, making it the centre that attracts workers in this sector; in addition, the city itself also provides many services (administrative, health, educational, commercial etc.).

b). The number of workers in the industrial sector has declined in recent years due to the decline in national policy relating to industrial development and the trend of most of the population towards the services sector. 
c). The city area represents $95 \%$ of the total area of the municipality, making employment rate in the agricultural sector very low. It should be noted that the city markets were developed in the colonial period, and before this, they were focused on agricultural products (primarily vegetables and fruits) which were and are still produced in the agricultural lands around the city, thus there being no need to bring products from external markets (Stamboul, 1957). Investments in services and the absence of a strategy at the national and local level to deal with the utilization and reconstruction of agricultural land surrounding the city have contributed to the changing role of agriculture in relation to services.

Table 1. Socio-economic indicators of the city of Médéa (1987-1998-2008). Source: Elaborated by authors based on data provided by the National Statistics Office in Algeria (ONS) (1987-1998-20o8).

\begin{tabular}{|c|c|c|c|c|c|c|c|}
\hline \multirow{2}{*}{ Years } & \multicolumn{2}{|c|}{ Agriculture } & \multicolumn{2}{|c|}{ Industry } & \multicolumn{2}{|c|}{ Services } & \multirow{2}{*}{ Total } \\
\hline & no. & $\%$ & no. & $\%$ & no. & $\%$ & \\
\hline 1987 & 972 & 4.93 & 7327 & 37.21 & 11393 & 57.86 & 19692 \\
\hline 1998 & 663 & 3.22 & 8082 & 39.33 & 11800 & 57.43 & 20545 \\
\hline 2008 & 805 & 2.95 & 11203 & 41.01 & 15308 & 56.04 & 27316 \\
\hline
\end{tabular}

Note: (ONS) The National Statistics Office is the Central Statistics institution in Algeria. It is a public administrative institution responsible for the collection, processing and dissemination of socio-economic statistical information (e.g. population and housing census, employment survey, industrial enterprises Survey, and other data domains) every 10 years. The data in (Table 1) and (Fig. 5) indicate the number of inhabitants who work in the economic sectors out of the total population of working age and who are counted at their workplaces during the period of the general census; however, they are not considered permanent employees because they are not registered in the government records of public service and this applies especially to those who work in the agricultural sector in general and in some activities in particular namely the service sector, including cafes and restaurants.

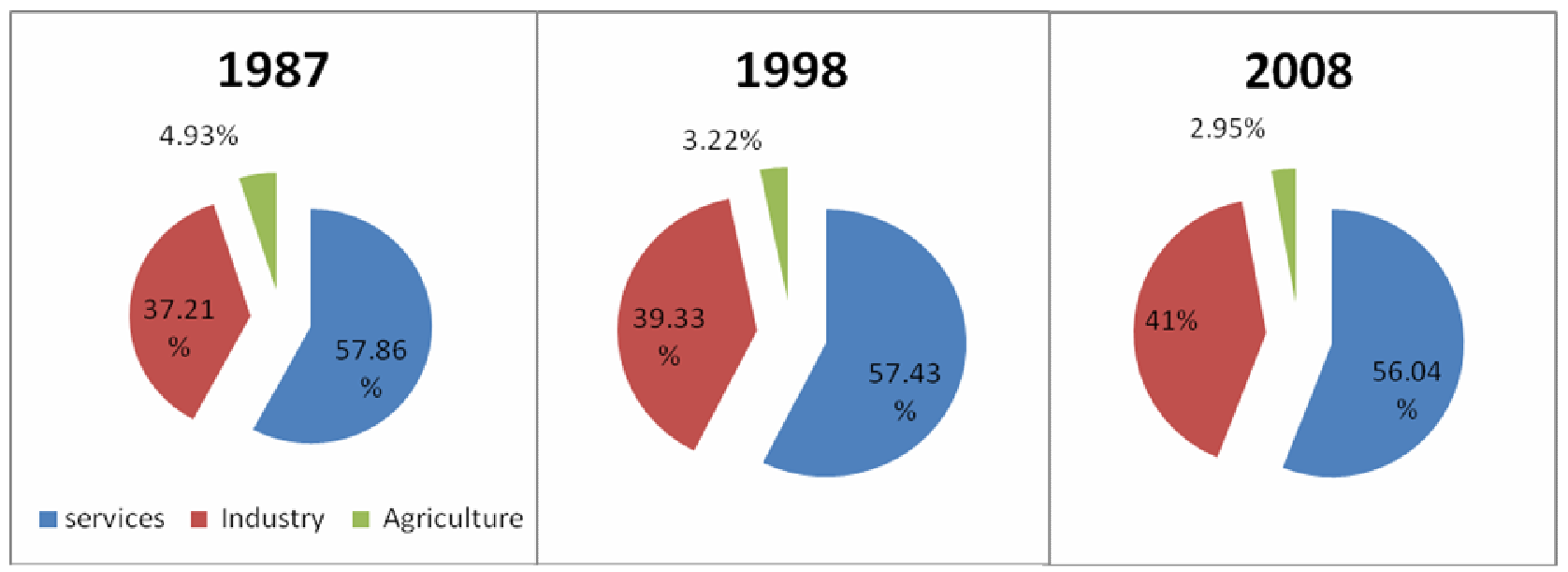

Fig. 5. Population distribution by economic sectors in the city of Médéa (1987-1998-2008).

d). The unplanned urban growth in the Atlas Mountains is not only depleting natural resources and disrupting ecosystem services, but also increasing the socio-economic and environmental inequalities both within towns and in their surrounding peri-urban zones. In addition, the rapid and unplanned urbanization is also increasing the susceptibility of intensively modified and densely populated fragile slopes to the active processes of mass movement and landslides (Fig. 6).

Furthermore, the rapidly changing climatic conditions, particularly the climate change induced hydrological extremes are posing severe threats to the sustainability of fast-growing urban ecosystems by increasing the frequency, intensity and severity of geohydrological hazards in towns and their vast hinterland.
This climate change is likely to trigger slope instability and disrupt the hydrological regime of urban watersheds, which are already under the stress of increasing urbanization. The city development plans and also the state disaster risk reduction frameworks and climate change adaptation plans did not make any provisions to address the emerging risks of climate change, particularly the geo-hydrological disasters in the fast-growing towns of the Atlas Mountains.

A large share of cultivated land and other areas are being encroached upon by the process of rapid urbanization and expansion of infrastructure, services and economic activities in the Atlas Mountains in the north part of Algeria, every year. Our study indicated that the most densely settled and rapidly growing urban centres of the Atlas Mountains have fast intruded into 
productive agricultural land in their surrounding rural areas, and this has already happened in Médéa (Fig. 7). This has caused a huge transformation of cultivated land within urban centres as well as in their peri-urban
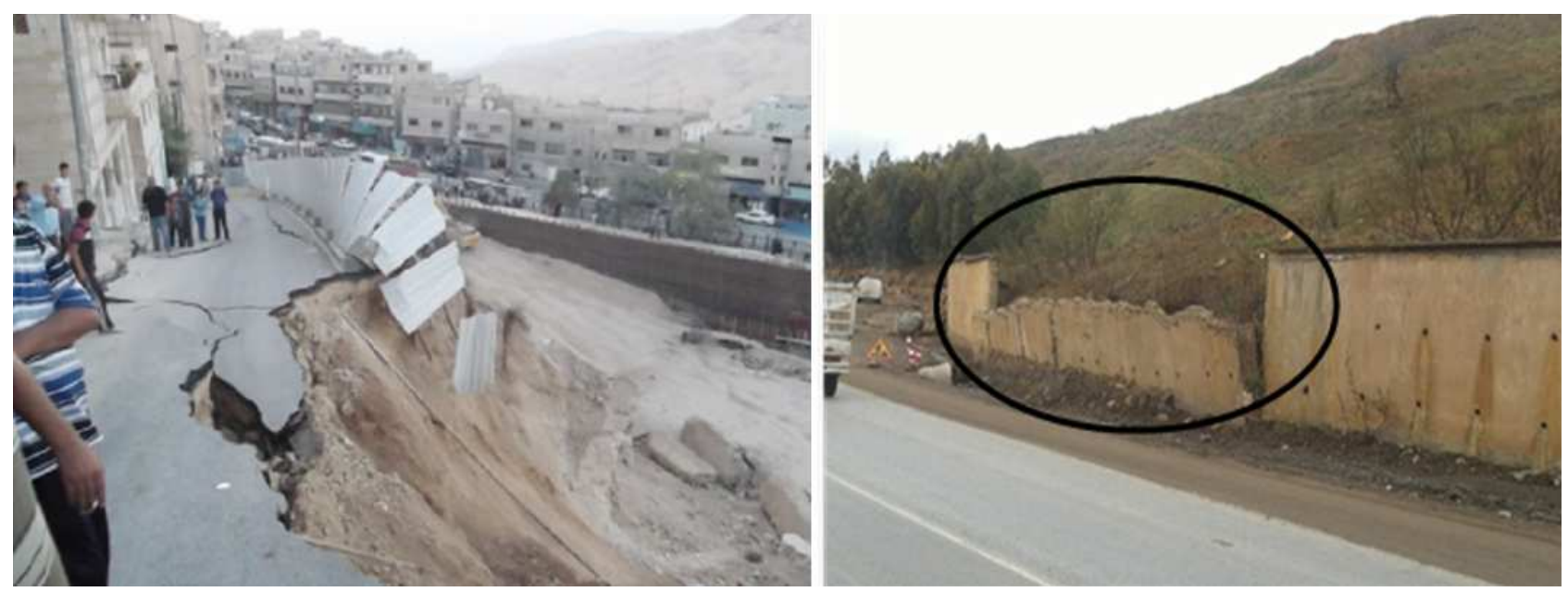

zones leading to land use intensification. Rural areas surrounding these urban centres have lost their prime agricultural land due to the expansion of urban land use in the urban fringe during the last 20 years.

Fig. 6. Landslides in Médéa (2018).

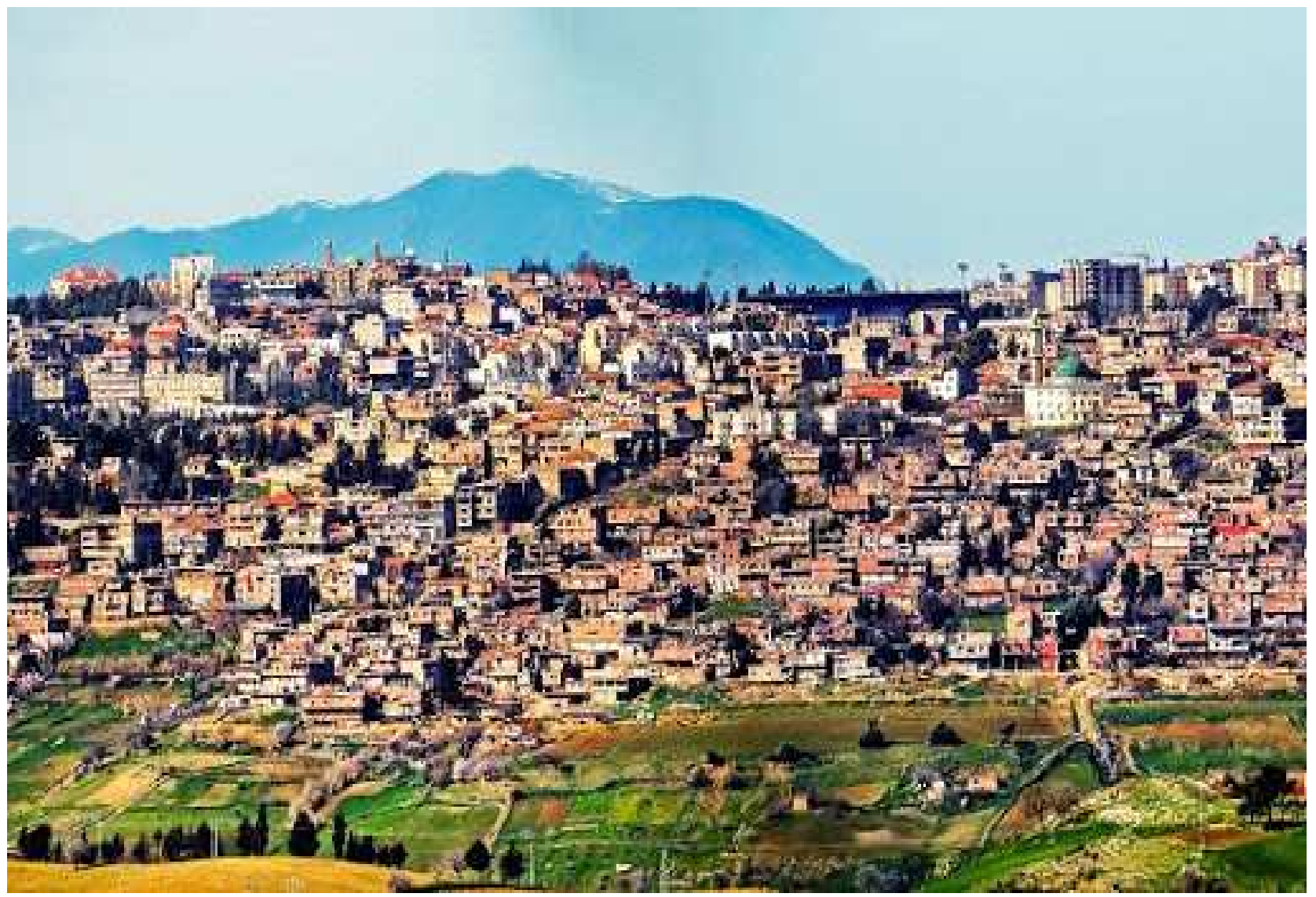

Fig. 7. Unplanned urbanization and encroachment on agricultural land in the eastern side of the city of Médéa (2018).

Overall, the rapid urbanization in the city of Médéa has been mainly determined by the increase in the number of migrants from rural areas in the period of 1987-1998 (Fig. 8). The security and political context during this period in Algeria has led to many people 
sector have been substantial. In the period 1998-2008, the number of migrants decreased by half, because of the improved security situation in Algeria after a period of 10 years of security instability and chaos in Algeria, resulting from the political crisis the country experienced between 1990-2000. This period was called the Black Decimal. It was also a period of considerable displacement of rural population to the main cities, which were the safest places to live and with the greatest abundance of jobs.

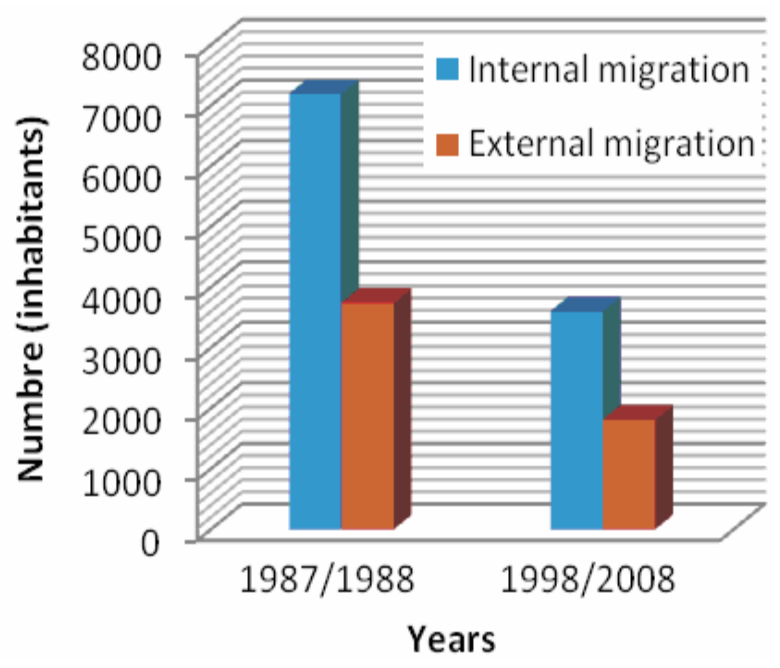

Fig. 8. Internal and external migration towards the city of Médéa (1987-1998 and 1998-2008).

However, this situation has left a void in rural areas. The Algerian Government adopted a rural development strategy aiming to halt the rural exodus towards the cities - for example by granting subsidies to rural residents to rebuild and renovate their homes and invest in farms and livestock.

\subsection{Environmental indicators}

An environmental strategy is part of a sustainable development process to ensure that human needs are satisfied with basic social rights and economic development without reducing the biological capacity of ecosystems to meet the needs of future generations (Chirisa et al., 2015; Riffat at al., 2016). Managing waste materials is a major preoccupation in cities and is clearly linked to the environment. Table 2 shows the quantity and types of waste generated in the city of Médéa and how they are managed.

Referring to Table 2 we note that:

a). There are impressive amounts of all-natural waste that are deposited in wild landfills or uncontrollable dumps without any sort of valid treatment and which are often located on stream beds or in the middle of the forest. Unfortunately for the atmosphere, incineration is the only means of disposal!

b). Collection and transport have had a major role in the process of evacuation of household waste, and this requires substantial means, which are divided into two operations:

- the collection of waste by inhabitants in front of their houses (Fig. 9) and/or at specific collection points;

- the transport of waste to the public landfill site;

- traders of the daily market often throw away their waste peel mixes thus creating micro-landfills;

- the non-compliance with the waste depositing hours on behalf of the inhabitants influences the cleanliness of the city.

Table 2. The different waste categories and how they are managed. Source: Plan directeur d'aménagement et d'urbanisme de la commune de Médéa (PDAU, 2011)”.

\begin{tabular}{l|lclll}
\multicolumn{1}{c|}{ Types de waste } & \multicolumn{1}{c}{ Sources } & $\begin{array}{c}\text { Quantities } \\
\text { (Tonnes/day) }\end{array}$ & \multicolumn{1}{c}{ Destination } & Management \\
\hline $\begin{array}{l}\text { Household and related } \\
\text { waste }\end{array}$ & $\begin{array}{l}\text { Inhabitants } \\
\text { Industrial Group of } \\
\text { Plastics - Rubbers } \\
\text { (ENPC) of Médéa }\end{array}$ & 276 & Public landfill of Médéa & Burnt \\
Polyethylene Film & $\begin{array}{l}\text { ENPC of Médéa } \\
\text { Mills of Médéa } \\
\text { Artisans of handcrafted } \\
\text { shoes }\end{array}$ & $\begin{array}{l}0,5 \\
\text { Polypropylene Film }\end{array}$ & Public landfill of Médéa & Burnt \\
$\begin{array}{l}\text { Dust } \\
\begin{array}{l}\text { Leather, leatherette, } \\
\text { miscellaneous packaging }\end{array}\end{array}$ & $\begin{array}{l}\text { Public landfill of Médéa } \\
\text { Public landfill of Médéa }\end{array}$ & Burnt & Burnt \\
\hline
\end{tabular}

Waste removal does not affect all agglomerations and areas: nonetheless, this context has caused the proliferation of random landfills in sensitive environments (agricultural land, alongside roads etc.) (Fig. 10), and the prolonged presence of these landfills can be detrimental to the safety of environment and therefore to the health of population. Due to uncovered waste and its composition (organic waste in decaying phase), foul odours are very strongly felt in the vicinity 52 of the landfill sites. The latter are often on fire due to the presence of combustible waste (e.g. paper, plastic and organic matter), causing long-lasting smoke. Smoke constitutes a sort of screen around waste discharge sites and results in olfactory and visual discomfort.

In conclusion, waste discharge does not in any way meet the technical and environmental standards for hygiene and environmental protection normally 
required in the operations of waste management. There are some practical projects that the local authorities have neglected to undertake in order to preserve the city environment and to reduce the dangers resulting from random dumping of waste. This requires the completion of some environmental projects in the city in order to protect the environment and reduce the risk of pollution.

We can suggest some of these environmental projects as follows:

- construction of a technical landfill away from the city in the Tamzgeda area;

- proof of the existence of a city park in Médéa (between the new pole and the city of Médéa).

- establishment of an environmental house in Médéa (a new urban centre).

- elimination of the lateral discharge of Draa
- establishment of new headquarters for environmental management at the level of the new urban centre.

- rehabilitation and development of a natural site in Tibhirine, a commune of Draa Samar.

It is important to note that the environmental dimension should be considered as a decisive entry in the design of the Médéa wilaya land use planning project in the long term. The fragility that characterizes the ecosystems in place, the degradation of soil and natural vegetation, the natural risks (erosion and flooding, and others), and the pollution of the valleys are all factors that need to be considered in this project. A second research project will be provided focusing on waste management and methods of waste collection in the city, and how the process of contributing to the environment is undertaken in the city.

\section{Samar.}

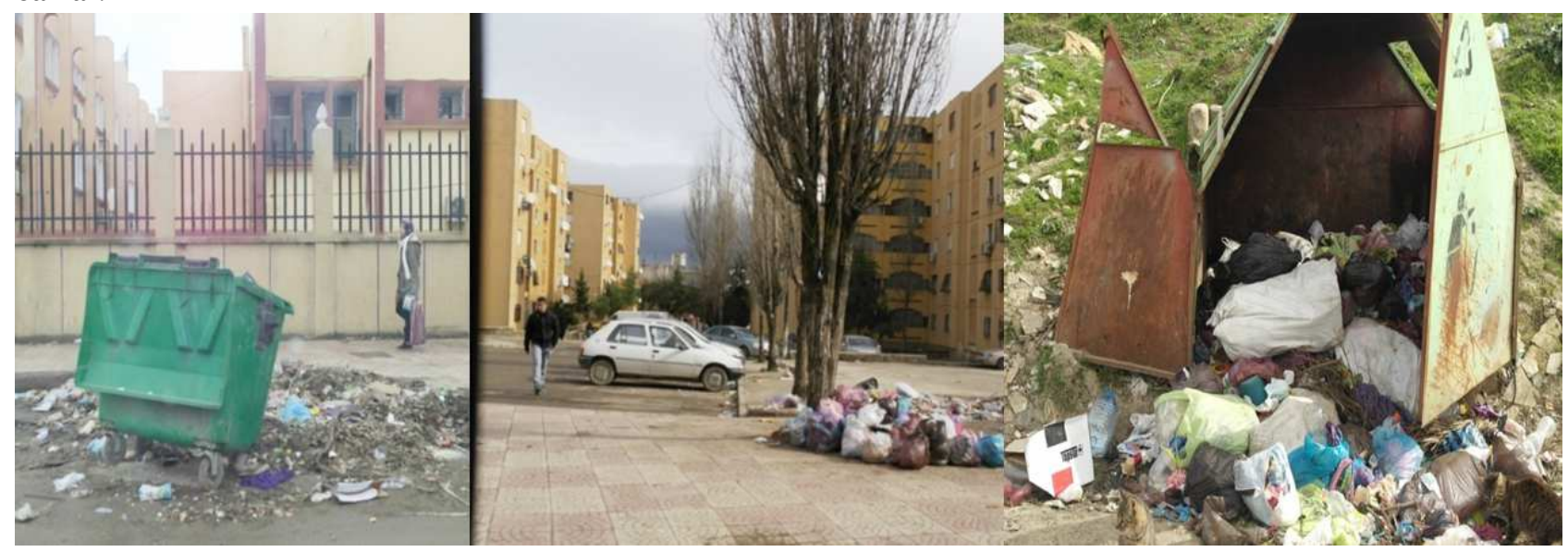

Fig. 9. Means Used for the Pre-Collection at the Household Level.

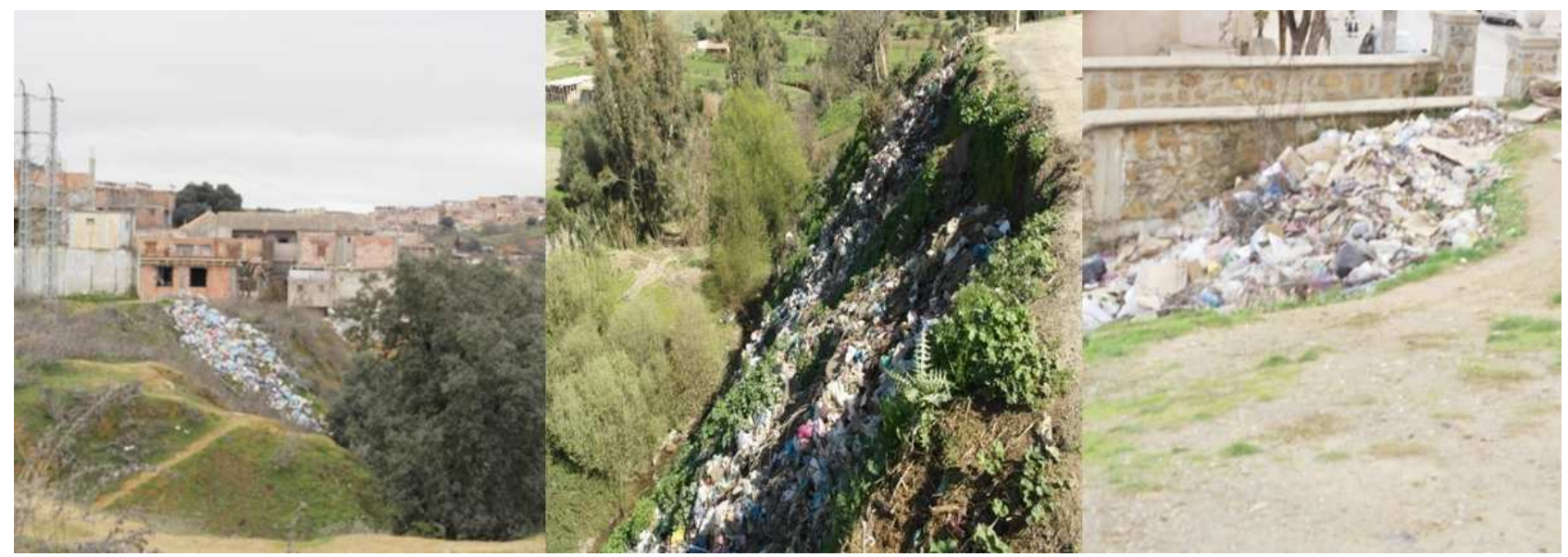

Fig. 10. Areas of random dumping of waste.

\section{CONCLUSION}

As in other parts of the world, urban growth cannot be stopped or reduced in the Atlas Mountains in the north of Algeria, but it can be steered in a more sustainable manner through integrated urban-rural land use planning. Effective land use policies need to be developed and implemented for the protection and conservation of forests, biodiversity, water resources and agricultural land. It is also imperative to develop a pragmatic framework for sustainable development of agriculture in the peri-urban zone as it is not only an important economic activity, but also a fundamental source of rural food and livelihood, an integral part of 
culture, history and traditions, and an invaluable treasure of traditional ecological knowledge required for adapting to climate change.

The results indicate that this mountainous city of Algeria has been known for major transformations in urban development after the colonial period. Urbanization has accelerated despite urbanization conditions, which were significantly affected by the rate of urbanization of mountainous cities and which have had a significant impact on the shape of the city.

The city of Médéa has a strong tendency and experience in the use of urban area to achieve development in the mountain areas of Algeria; through the social and economic indicators studied, results show that the majority of the city population is engaged in the service sector (more than 56\%) although the region is rural in nature.

In relation to the growth and expansion of the city without taking into account the roles and the natural landscape of the city, it has resulted in a serious environmental problem in the city and its suburbs due to the high quantity of waste of all kinds produced daily, without the use of proper methods in the process of collection, transport and waste treatment. Waste is frequently burned or thrown into natural areas, affecting the landscape surrounding the city, especially the mountainous regions of Algeria.

It is necessary to develop a planning policy for the mountainous cities in Algeria to achieve sustainable development in line with the development goals in the mountainous cities based on maintaining the functional role of the urban area and landscape. This partly reflects the fact that Algerians have not yet adopted the concept of sustainability.

In another article under preparation, we will investigate the approaches of how to conserve agricultural land and farm activities in the peri-urban and rural areas around the city of Médéa by investigating how such conservation practices have been successful in some jurisdictions (e.g. Québec in Canada) (Bryant and Loudiyi, 2017).

In addition, we will investigate the pitfalls of classical land use planning in the field of conservation and how different forms of strategic planning for agricultural development can make a tremendous difference (Bryant et al., 2018) and how this can be integrated into an action research process involving not just researchers but also representatives of the city and municipality, representatives of the farmers and representatives of citizens (Bousbaine and Bryant, 2015).

\section{ACKNOWLEGMENTS}

We thank all the administrative bodies in the city of Médéa for helping us gather data for this research.

\section{REFERENCES}

Schild A., Sharma E. (2011), Sustainable Mountain Development Revisited. Mountain Research and Development, 34(3),237-241. DOI: 10.1659/MRDJOURNAL-D-11-00069.1.

Beniston M. (2003), Climatic Change in Mountain Regions: A Review of Possible Impacts. Climatic Change, 59(1), 5-31. DOI: https://doi.org/10.1023/ A:1024458411589

Blyth S., Groombridge B., Igor M., Newton A. (2002), Mountain Watch. Environmental Change and Sustainable Development in Mountains. UNEP World Conservation Monitoring Centre (WCMC): Cambridge, UK ISBN: 1-899628-20-7.

Bousbaine A., Bryant C. (2015), The integration of action research and traditional field research to provide sustainable solutions to maintaining peri-urban agriculture. Geographical Research, 54(2), 176-186. DOI: https://doi.org/10.1111/1745-5871.12134

Bryant C., Loudiyi S. (2017), Des espaces agricoles dans la metropolisation. Perspectives francoquébecoises. L'Harmattan. ISBN: 978-2-343-13249-5.

Bryant C., Bousbaine A., Akkari C. (2018), Strategic Planning for Development and Conservation and the Roles of Citizens, International Journal of Avian \& Wildlife Biology, 3(3),81-83. URL: http://medcraveonline.com/IJAWB/IJAWB-03-00060 . pdf

Carrier H., Laurent P. (1966), Le Phénomène Urbain. Annales. Economies, Sociétés, Civilisations, 21(4), 922-923. URL: https://www.persee.fr/doc/ ahess_0395-2649_1966_num_21_4_421437_t1_0922 _oooo_2

Ding Y, Peng J. (2018), Impacts of Urbanization of Mountainous Areas on Resources and Environment: Based on Ecological Footprint Model. Sustainability, 10 (3), 765. DOI: 10.339o/su10030765.

Du C. (2009), On the Mountain Urban Landscape Studies, Science in China Series E: Technological Sciences, 52(9), 2497-2501. DOI: https://doi.org/10. 1007/s11431-009-0268-0.

Huang G. (2006), Theory of Mountain Urbanology, Beijing: China Architecture \& Building Press.

The Panos Institute (2002), High Stakes: The Future for Mountain Societies, Panos Report No 44, Abceda General Printing Co, London, UK, P 6.

Ghosh P. (2007), Urbanization: A Potential Retreat to the Fragile Himalayan Environment. Current Science, 93(2), 126. URL: https://www.currentscience.ac.in/ $\mathrm{php} /$ toc.php?vol $=093 \&$ issue $=02$

Gurung A. B., Wymann von Dach S., Price F. M., Aspinall R. Balsiger J., Baron J. S., Sharma E., Greenwood G., Kohler T. (2012), Global Change and the World's Mountains: Research Needs and Emerging Themes for Sustainable Development. Mountain Research and Development, 32(S1), 47-54. 
DOI: http://dx.doi.org/10.1659/MRD-JOURNAL-D-11ooo84.S1

International Centre for Integrated Mountain Development (ICIMOD) (2012a), Framework for Valuing Ecosystem Services in the Himalayas. ICIMOD Technical report. Contributors Rasul G., Chettri N., Sharma E., Kathmandu, Nepal. DOI: 10.13140/ 2.1.4828.8962

International Centre for Integrated Mountain Development (ICIMOD) (2012b), Climate Change Challenges in the Mountains: Implication to Adaptation Needs of the Hindu Kush Himalayas. Hayama: Institute for Global Environmental Strategies, Nepal.

Chirisa I., Dirwai S. O., Matamanda A. (2015), A review on the systems approach for solving the complexity of the environmental problematique of cities in Africa, Future Cities and Environment, 1, No 11, 1-10. DOI: https://doi.org/10.1186/s40984-015-0010-y

Jansky L., Ives J. D., Furuyashiki K., Watanabe T. (2002), Global mountain research for sustainable development. Global Environmental Change, 12(3), 231-239. DOI: https://doi.org/10.1016/So959-3780 (02)00015-8

Medina do Nascimento J. (2009), La croissance et le système de gestion et de planification de la ville de Praia, (Rep. Du Cap-Vert). These de doctorat, Universite de Rouen. URL: https://pdfs.semantic scholar.org/do34/1982443f5oca87794e176b6eff22d3b d1dod.pdf?_ga=2.104246464.1568252013.15939451311038326244.1593945131.

Kreutzmann H. (2001), Development Indicators for Mountain Regions. Mountain Research and Development, 21(2), 132-139. DOI: http://dx.doi.org/ 10.1659/0276-4741(2001)021[0132:DIFMR]2.o.CO;2

Liu Y., Li L., Chen L., Cheng L., Zhou X., Cui Y., Li H., Liu W. (2019), Urban growth simulation in different scenarios using the SLEUTH model: A case study of Hefei, East China. PLoS ONE 14(11), e0224998. DOI: https://doi.org/10.1371/journal.pone. 0224998

Löffler J., Anschlag K., Baker B., Finch O. D., Diekkrüger B., Wundram D., Schröder B., Pape R., Lundberg A. (2011), Mountain Ecosystem Response to Global Change, Erdkunde, 65(2), 189-213.

Maselli D. (2012), Promoting Sustainable Mountain Development at the Global Level. The Swiss Development Cooperation's Involvement. Mountain Research and Development, 32(S1), 64-70. http://www.jstor.com/stable/mounresedeve.32.s1.s64

Ministère de l'Équipement et de l'Aménagement du Territoire (MEAT) (2003), Demain L'Algérie, 1250.

Obudho R. (1976), Social Indicators for Housing and Urban Development in Africa, Towards a New
Development Model, Social Indicators Research, 3(3/4), 431-449. URL: https://www.jstor.org/stable /27521800

Office National des Statistiques (ONS) (2008), Rapport de Recensement de la Population et de l'Habitat, Ministère des Finances, Algérie.

PDAU (2011), Révision du Plan Directeur d'Aménagement et d'Urbanisme de la Commune de Médéa. Direction d'urbanisme de la Wilaya de Médéa, 1-20.

Riffat S., Powell R., Devrim A. (2016), Future Cities and Environmental Sustainability, Future Cities and Environment, 2 (1), 1-23. DOI: 10.1186/s40984-0160014-2

Angel S., Parent J., Civco D. L., Blei A. M. (2012), Atlas of Urban Expansion. ISBN: 978-1-55844-243-6. URL: https://www.lincolninst.edu/sites/default/files/ pubfiles/atlas-of-urban-expansion-chp.pdf

Tiwari P. C., Tiwari A., Joshi B. (2018), Urban Growth in Himalaya: Understanding the Process and Options for Sustainable Development, Journal of Urban and Regional Studies on Contemporary India 4(2): 1527. URL: https://ir.lib.hiroshima-u.ac.jp/files/public /4/45582/20180418103822469299/JURSCI_4-2_15. pdf

Stamboul J. (1957), Enquête Sur la Ville de Médéa, F.C. Paris.

Stren R. E., White R. R., Whitney J. B. (1992), Sustainable Cities. Urbanization and the Environment in International Perspective. Oxford: Westview Press: Boulder, CO, USA. ISBN-10: 081338169X

Verburg P. H., Schot P. P., Dijst M. J. Veldkamp A. (2004), Land use change modelling: current practice and research priorities. GeoJournal 61, 309-324. DOI: https://doi.org/10.1007/s10708-004-4946-y

Wang Z., Lu C. (2018), Urban Land Expansion and its Driving Factors of Mountain Cities in China During 1990-2015, Journal of Geographical Sciences, 28(8), 1152-1166. DOI: 10.1007/s11442-018-1547-o

Wei C. (2001), Discrimination of the Concept of our Country's Mountainous City, Huazhong Architecture, 19(3), 55-58.

Zhang J., Wei D., Shaoquan L. (2015), Geographical Space Development Zone Classification: An Essential Guide for Transformation of Mountain Resource Cities. Chinese Geographical Science, 25(3), 361-374. DOI: https://doi.org/10.1007/s11769-0150755-0 